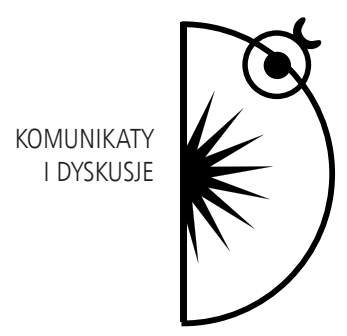

Sławomir Pasikowski

\title{
Transparentność w publikowaniu wyników badań empirycznych poświęconych edukacji
}

DOI: http://dx.doi.org/10.12775/PBE.2013.008

Sposób dochodzenia do określonych stwierdzeń, stosowana argumentacja, ale też organizacja treści wypowiedzi przeznaczonej do publikacji podlegają zestawom kryteriów, których spełnienie decyduje o akceptacji tekstu przez społeczność naukową.

Do najogólniejszych oczekiwań należy formułowanie nowych wyjaśnień, uzupełnień i aplikacji istniejących teorii i wyników badań. Obok tego społeczność naukowa wymaga jednak w nie mniejszym stopniu, by rekonstrukcja oraz interpretacja tych teorii i badań były dokonywane zgodnie z dotychczas obowiązującymi regułami (Bourdieu 1984; Buczkowski, Klawiter 1985; Klawiter 1989). Zbyt duże od nich odstępstwa narażają na odrzucenie tekstu lub nawet ostracyzm. Jest to dość oczywiste i pewnie niewiele znajdzie się takich osób, które sądzą, że głównie kreatywność i oryginalność są receptą na zdobycie uznania w społeczności skupionej wokół jakiejś dyscypliny naukowej.

Pośledniejsze zestawy kryteriów różnią się w zależności od charakteru tekstu. Innych bowiem właściwości oczekuje się od tekstów przeglądowych i teoretycznych (Sternberg 2011; Eagly 2011), a innych od raportów z badań czy też tekstów, w których głównym sposobem argumentacji podczas rozstrzygania zasadności postawionej tezy są wyniki przeprowadzonych badań empirycznych (Cohen, Manion, Morison 2007; Tesser, Martin 2011; Sternberg, Grigorenko 2011; Urbaniak-Zając 2006, 2010). Mój głos dotyczy tej drugiej kategorii pu- 
blikacji i skupia się wyłącznie na jednej spośród wielu właściwości podnoszonych w metodologicznym dyskursie o współczesnych standardach publikacji naukowych. Mowa o przywołanej w tytule transparentności jako zasadzie zwiększania wiarygodności prezentowanych rezultatów badawczych.

Zacznę od sformułowania stanowiska, że prowadzenie badań empirycznych jest nieodzownie związane $\mathrm{z}$ akceptacją założeń realizmu i korespondencyjnej koncepcji prawdy, choćby w słabej ich odmianie (por. Aranowska 2005; Urbaniak-Zając 2011). Aby bowiem gromadzić informacje o obiektach otaczającej rzeczywistości, a następnie na tej podstawie orzekać o właściwościach tych obiektów, trzeba przyjąć przynajmniej względną niezależność istnienia podmiotu i przedmiotu poznania oraz możliwość orzekania sądów zgodnych ze stanem możliwym do zaobserwowania (por. Woleński 2007, s. 160-164). W przeciwnym wypadku stanowisko empiryczne traci sens i bezzasadne stają się obserwacje mające na celu ustalenie tego, jak jest. Nawet wtedy, gdy ustalanie tego, ,jak jest", dotyczy tylko deklarowanego punktu widzenia. Nauki o edukacji, koncentrując się na człowieku oraz procesach społecznych związanych z jego rozwojem i funkcjonowaniem, wkraczają na obszar empirii tylekroć, ilekroć próbuje się w ich ramach określać kondycję konkretnych osób i warunki, w jakich przyszło im funkcjonować. Z punktu widzenia określonej społeczności naukowej wiarygodność dokonywanych obserwacji i stwierdzeń formułowanych na ich podstawie zależy od poprawności rozwiązań metodologicznych przyjętych w tej społeczności. Dlatego tak szczególnego znaczenia w procesie publikowania wyników badań wydaje się nabierać transparentność ich przebiegu, dająca odbiorcom możliwość weryfikacji wniosków, bez której są oni narażeni na niebezpieczeństwa związane z subiektywizmem, nieuprawnionym uogólnianiem oraz dowolnością interpretacji danych gromadzonych w trakcie procesu badawczego (por. Bowen 2009; Urbaniak-Zając 2011). Najczystsze bowiem intencje nie gwarantują uniknięcia pułapek, które czyhają na badaczy samotnie poszukujących odpowiedzi na stawiane pytania, szczególnie takie, które dotyczą tak złożonego zagadnienia, jakim jest edukacja (por. Wrigley 1976). Wymóg owej transparentności wynika z powszechnego przyjęcia zasad intersubiektywnej komunikowalności i intersubiektywnej sprowadzalności, uzyskujących spełnienie w drodze publikowania otrzymywanych rezultatów, wystawiania ich na krytykę środowiska naukowego oraz replikowania samych badań (np. Such, Szcześniak 1997; Brzeziński 1999; Urbaniak-Zając 2006). Notabene, u podstaw tych zasad leży idea racjonalizmu (Woleński 2007), która według niektórych stanowisk charakteryzuje podejście empiryczne w badaniach naukowych w ogóle (por. Heller 2011). 
Wprawdzie można by oczekiwać, że wewnętrzna dyscyplina autora zabezpiecza przed formułowaniem sądów zbyt ogólnych, kategorycznych czy wartościujących wtedy, gdy podstaw do oceny brak. Jej osiągnięcie stanowi jednak nie lada wyzwanie, szczególnie dla niedoświadczonych autorów. W tej sytuacji środkiem wspomagającym może być właśnie transparentność w prezentowaniu własnego stanowiska i wyników przeprowadzanych obserwacji. Wystawienie na widok publiczny kolejnych kroków procedury badawczej pozwala poddać je ocenie społeczności naukowej, ale też zabezpiecza przed interpretacjami niezgodnymi z komunikacyjnymi intencjami autora. Autor stwarza w ten sposób czytelnikowi możliwość wglądu w przebieg procesu badawczego i wykorzystanych procedur, a tym samym pozwala na ocenę wiarygodności formułowanych wniosków. Sam z kolei, kierując się zasadą transparentności, ma okazję na dokonanie, już podczas tworzenia publikacji, krytycznego osądu własnych twierdzeń i ewentualnego ich korygowania. Oczywiście, postępowanie zgodnie $\mathrm{z}$ tą zasadą wymaga odwagi i uczciwości.

Transparentność wydaje się dla autora wartościową właściwością także z innego powodu, i to niezależnie od przyjętej orientacji metodologicznej. O ile bowiem czytelnik może nie zgadzać się z treścią konkretnych stwierdzeń, o tyle zaprezentowanie kolejnych kroków rozumowania ${ }^{*}$ i podstaw formułowanych sądów zamyka wypowiedź autora w granicach modelu czy konkretnego podejścia teoretycznego, które autor przyjął. Tym sposobem wypowiedź ta staje się koherentna z wyjściową perspektywą teoretyczną, co zabezpiecza ją przed dowolnością interpretacji, wieloznacznością, o którą autor nie zabiega, i co dodatkowo może właśnie sprzyjać precyzyjności komunikacji dokonywanej za pośrednictwem tekstu. A tu chodzi przecież o komunikację i obustronne zrozumienie zagadnienia, którego ów tekst dotyczy.

\section{Bibliografia}

Aranowska E. (2005), Pomiar ilościowy w psychologii, Wydawnictwo Naukowe Scholar, Warszawa.

Bourdieu P. (1984), Specyfika dziedziny naukowej i społeczne warunki rozwoju wiedzy, w: E. Mokrzycki (red.), Kryzys i schizma. Antyscjentystyczne tendencje $w$ socjologii wspótczesnej, t. 2, PIW, Warszawa.

\footnotetext{
* Zakładając ich logiczną poprawność.
} 
Bowen G. A. (2009), Supporting a grounded theory with an audit trail: an illustration, „International Journal of Social Research Methodology”, Vol. 12 (4), s. 305-316, http://dx.doi.org/10.1080/13645570802156196.

Brzeziński J. (1999), Metodologia badań psychologicznych, PWN, Warszawa.

Buczkowski P., Klawiter A. (1985), Rekonstrukcje, interpretacje, rozwinięcia. Przedmowa, „Poznańskie Studia z Filozofii Nauki”, z. 9, s. 5-16.

Cohen L., Manion L., Morrison K. (2007), Research Methods in Education, Routledge, London-New York.

Eagly A. H. (2011), Recenzowanie przegladów literatury złożonych do publikacji w czasopiśmie, w: R. J. Sternberg, Recenzowanie prac naukowych w psychologii, Wyd. Paradygmat, Warszawa.

Heller M. (2011), Filozofia nauki. Wprowadzenie, Petrus, Kraków.

Klawiter A. (1989), Trzy postawy wobec nauki - uczestnik, rozumiejacy obserwator, badacz, „Poznańskie Studia z Filozofii Nauki”, z. 11, s. 11-28.

Sternberg R. J. (2011), Recenzowanie artykułów teoretycznych, w: R. J. Sternberg, Recenzowanie prac naukowych w psychologii, Wyd. Paradygmat, Warszawa.

Sternberg R. J., Grigorenko E. L. (2011), Recenzowanie artykułów empirycznych pod wzgledem metodologicznym, w: R. J. Sternberg, Recenzowanie prac naukowych w psychologii, Wyd. Paradygmat, Warszawa.

Tesser A., Martin L. (2011), Recenzowanie prac empirycznych złożonych do czasopism, w: R. J. Sternberg, Recenzowanie prac naukowych w psychologii, Wyd. Paradygmat, Warszawa.

Urbaniak-Zając D. (2006), W poszukiwaniu kryteriów oceny badań jakościowych, w: D. Kubinowski, M. Nowak (red.), Metodologia pedagogiki zorientowanej humanistycznie, Impuls, Kraków.

Urbaniak-Zając D. (2010), O stosowaniu hipotez w badaniach pedagogicznych, w: J. Piekarski, D. Urbaniak-Zając, K. Szmidt (red.), Metodologiczne problemy tworzenia wiedzy w pedagogice. Oblicza akademickiej praktyki, Impuls, Kraków.

Urbaniak-Zając D. (2011), Badania jakościowe jako źródło (naukowej) wiedzy pedagogicznej, w: T. Hejnicka-Bezwińska (red.), Pedagogika ogólna. Dyskurs o statusie naukowym i dydaktycznym, Wydawnictwo UKW, Bydgoszcz.

Woleński J. (2007), Epistemologia. Poznanie, prawda, wiedza, realizm, PWN, Warszawa.

Wrigley J. (1976), Pitfalls in Educational Research, "BERA Bulletin", Vol. 3(1), s. 1-7, http://dx.doi.org/10.1080/0141192760020201. 


\section{Transparency in publishing results of empirical research on education}

\section{Summary}

Transparency is a one of the crucial criteria in educational research. Researchers are sensitized by transparency in the scope of advantage and disadvantage aspects of research project. It protects readers as well as authors from illegal inferences and distant associations which are beyond the reach of research project. Transparency provides conditions to verification of presented research results. 